\title{
A delimitação legal dos espaços urbanos
}

\author{
Maria Helena Palmer Lima
}

Uma das linhas de pesquisa tradicional da geografia, os critérios que delimitam os espaços urbanos e rurais constituem tema central de uma visão geográfica do Brasil na contemporaneidade.

Com efeito, a delimitação de espaços urbanos no Brasil tem implicações no controle do território, o que faz com que seu estabelecimento ocorra por meio de legislação específica nas diversas esferas do poder constituído.

Historicamente, o ordenamento do Território Nacional produziu os primeiros resultados ao oferecer consistência aos recenseamentos gerais da população, que passaram a ser periódicos e padronizados para todo o País, fornecendo informações importantes para o conhecimento do Brasil e a elaboração de políticas públicas.

A determinação legal dos espaços urbanos no Brasil, contudo, vem recebendo críticas de importantes estudiosos ligados principalmente à geografia. O texto, a seguir, recupera a evolução dessa legislação e apresenta as críticas a ela dirigida.

\section{Questões empíricas e conceituais em torno da delimitação legal do espaço urbano no Brasil}

A primeira orientação para delimitação do território brasileiro em espaços urbanos e rurais foi apresentada pela Convenção Nacional de Estatística, em 11 de agosto de 1936, na qual ficou estabelecido pelos governos federal e das Unidades da Federação que todas as municipalidades fixariam, naquele ano, "os limites e a área do 'quadro urbano' da cidade ou vila sede do município" (CONVENÇÃO...,1936, p. 22). 
Ainda em 1936, as sedes municipais podiam ser cidades ou vilas, categorias atribuídas no momento de suas criações e cuja origem remonta ao Brasil Colônia. As cidades só podiam ser constituídas pelo poder real, enquanto que aos donatários das capitanias era permitido apenas criar as vilas (ABREU, 2010).

Como o desenvolvimento socioeconômico ocorreu de forma diferenciada, muitas vilas progrediram e cresceram mais acentuadamente em relação a várias outras cidades. Independentemente da designação e do seu porte populacional ou econômico, em todas, o governo, com suas evidências formais, se fazia presente.

O Decreto-Lei n. 311, de 02.03.1938, como será visto adiante no tópico intitulado A legislação brasileira e sua origem, determinou que as sedes de municípios seriam classificadas como cidades, e as sedes de distritos, como vilas. As Unidades Federadas deveriam indicar os municípios e os distritos existentes naquele momento e os que fossem criados a partir de então deveriam obedecer ao estabelecido no referido Decreto-Lei (BRASIL, 1938).

Essa legislação organizou a estrutura territorial brasileira atribuindo-lhe forte sentido político-administrativo, uma vez que as cidades e vilas, além de serem, respectivamente, as sedes de municípios e distritos, passaram também a ser os únicos espaços urbanos, cujos limites são, desde o início, determinados por leis municipais.

A despeito de todas as críticas, essa legislação vem se mantendo por quase oito décadas, resistindo a quatro especiais oportunidades de alteração como foram as Constituições Federais do Brasil de 1946; 1967; 1988 (BRASIL, 1986, 2009); e ainda o Estatuto das Cidades de 2001 (BRASIL, 2001), Lei n. 10.257, de 10.07.2001, significando sua aprovação pelo Estado brasileiro.

Deve-se admitir que algumas situações, como é o caso da classificação de espaços urbanos e rurais, requerem permanência para efeitos de comparação temporal. Nesse caso específico, há a manutenção da definição geral; entretanto, as delimitações de cada um dos perímetros urbanos de todas as cidades e vilas são estabelecidas pelos governos municipais e podem variar conforme a necessidade local, a depender de suas leis.

Rosa e Ferreira (2006) apresentam o exemplo do Município de Araraquara, no Estado de São Paulo, onde loteamentos que, na avaliação das autoras, deveriam constar da área urbana, foram incluídos na área rural pelo Censo Demográfico 2000 por falta de atualização da legislação municipal. Para outros autores, como Veiga (2002a), há, ao contrário, populações que no seu entender deveriam estar entre as rurais, mas são legalmente urbanas.

Os Gráficos 1 e 2 apresentam, respectivamente, o aumento do número de municípios e o da população urbana no Brasil para os mesmos momentos na linha do tempo. Observa-se que, enquanto a curva dos municípios apresenta comportamentos diferentes nos períodos, a curva de população urbana é permanentemente crescente. $O$ incremento da população urbana está, portanto, muito mais ligado ao adensamento das áreas urbanas já consolidadas do que ao surgimento de novas áreas urbanas por meio das emancipações municipais. 


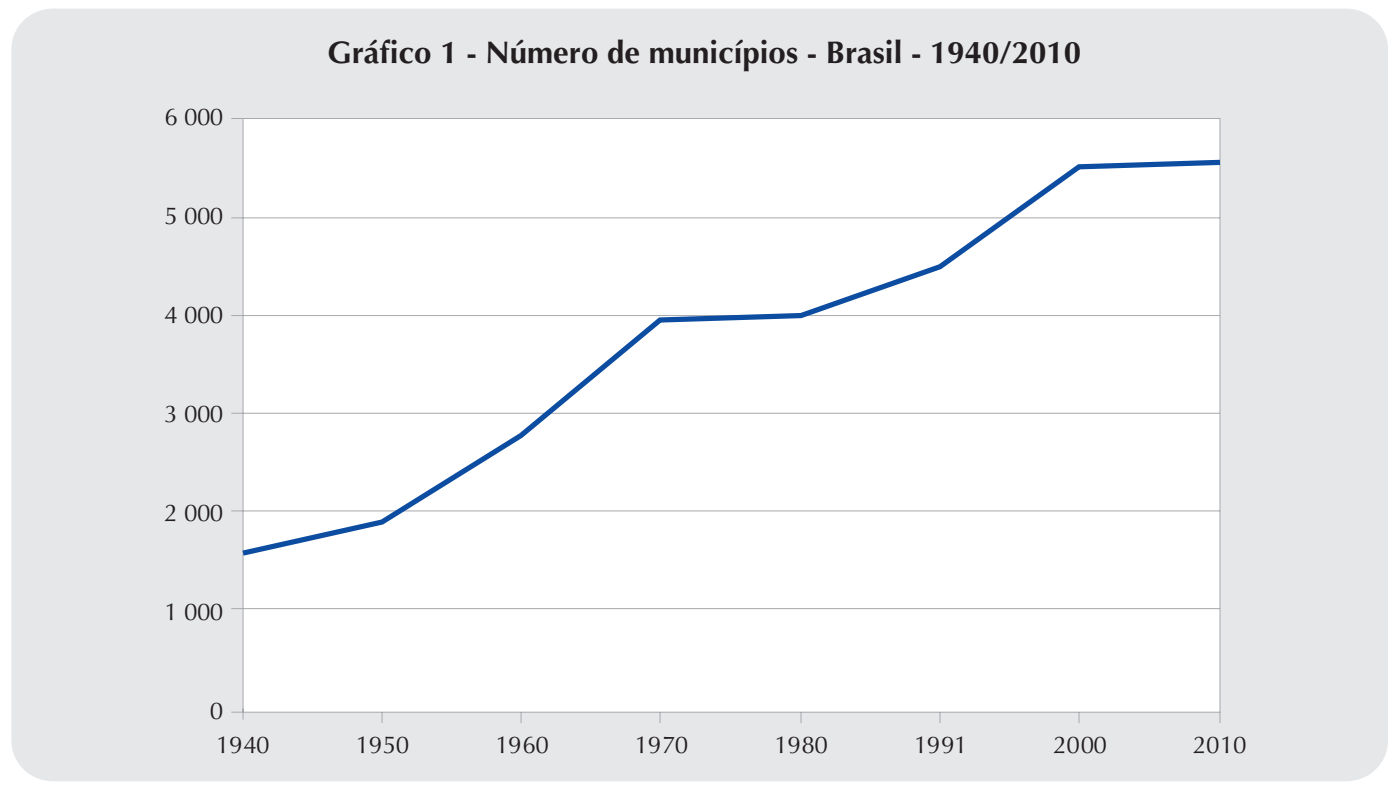

Fonte: IBGE, Censo Demográfico 1940/2010.

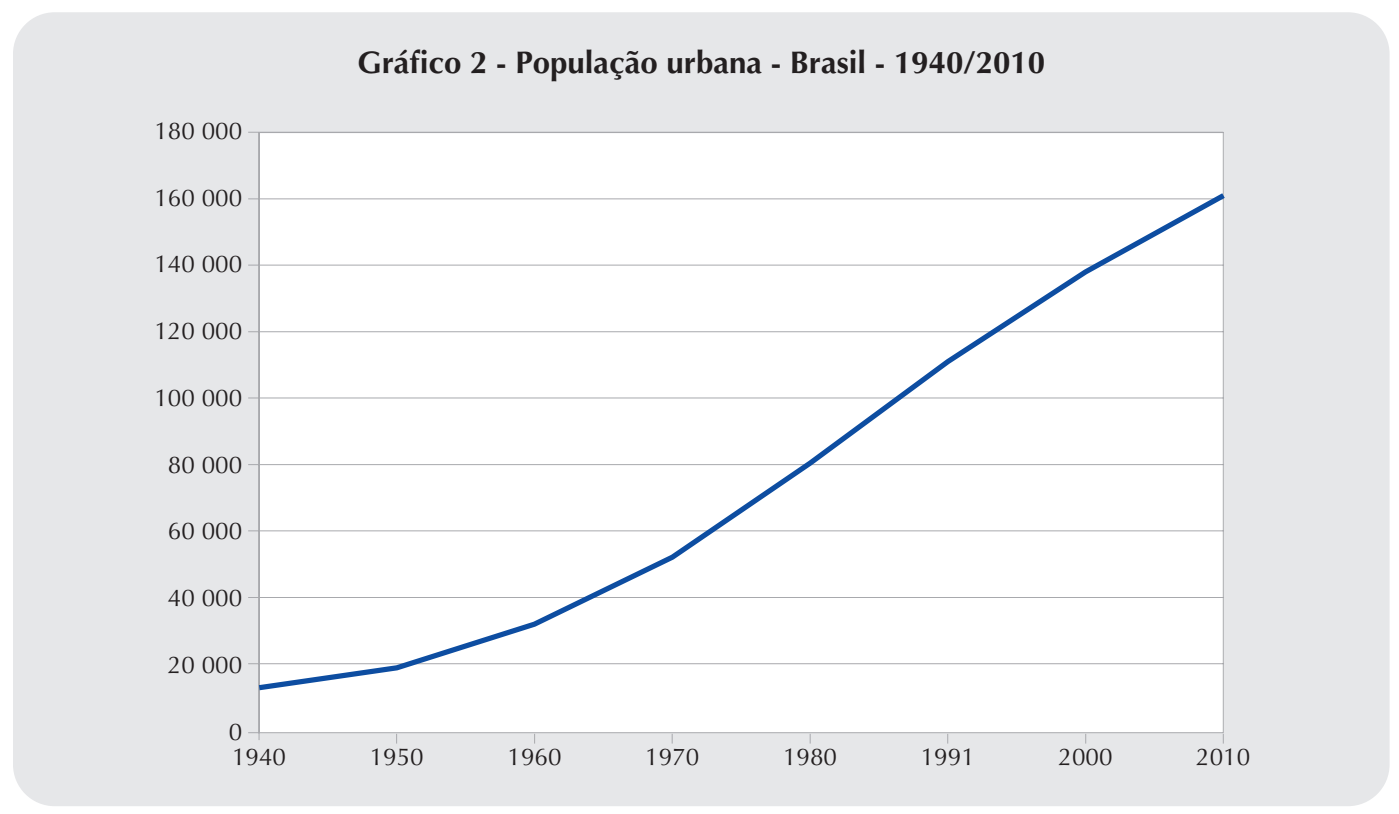

Fonte: IBGE, Censo Demográfico 1940/2010.

Os mapas, a seguir, apresentam momentos da distribuição da população urbana brasileira em municípios, deixando evidenciada a intensa urbanização da população, decorrente não apenas do aumento do número de municípios e, consequentemente, de áreas urbanas, vale dizer de cidades e vilas, mas, principalmente, do adensamento da população em áreas urbanas consolidadas como as atuais metrópoles, como mostraram os Gráficos 1 e 2. 
Mapa 1 - Evolução da população urbana - 1940

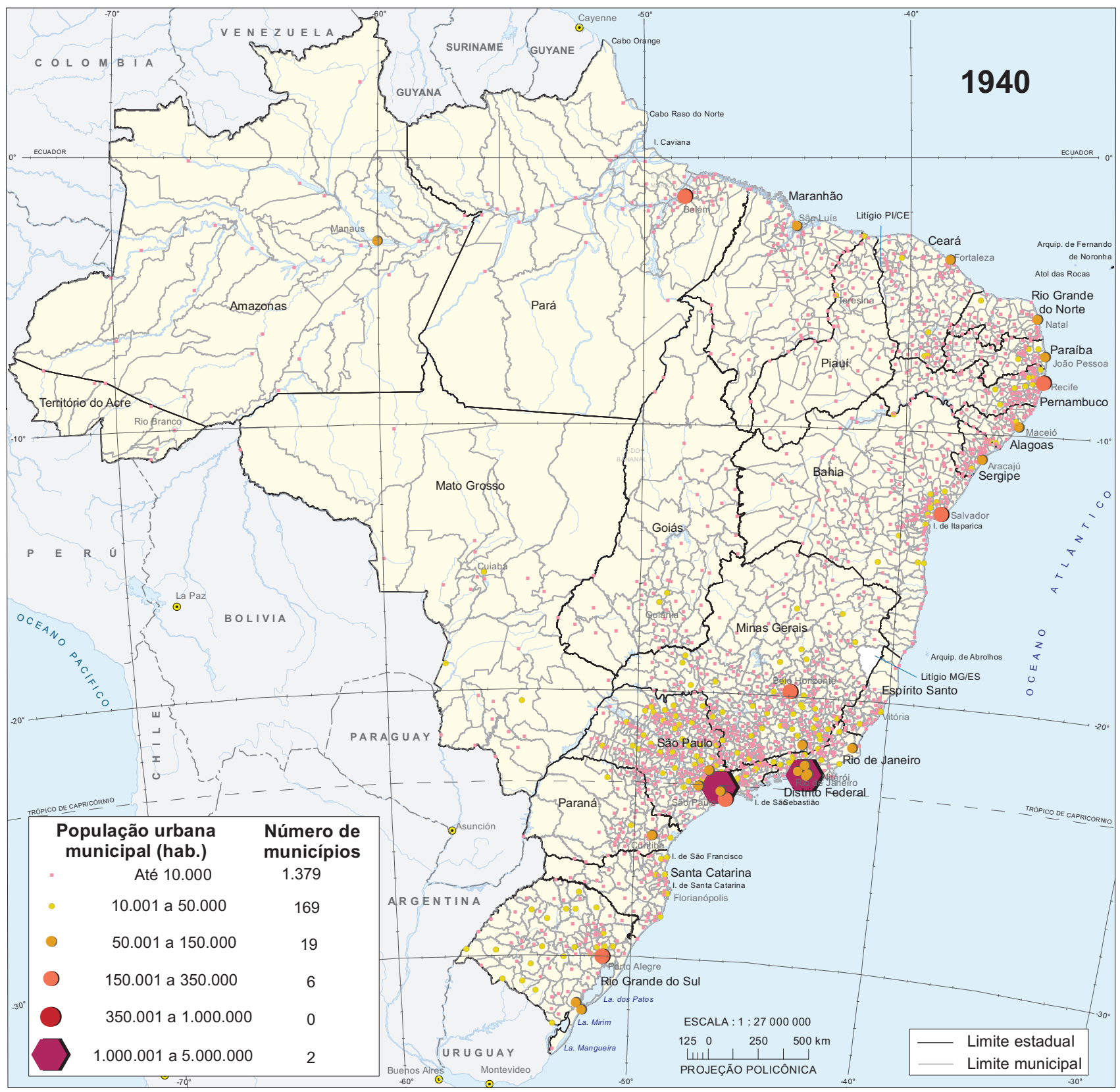

Fonte: IBGE, Censo Demográfico 1940.

Notas: 1. Primeiro censo realizado pelo IBGE quando a população passou a ser legalmente dividida entre urbana e rural.

2. Surgiram os litígios entre Minas Gerais e Espírito Santo e entre Piauí e Ceará.

3. A capital do Estado de Goiás foi transferida para Goiânia. 
Mapa 2 - Evolução da população urbana - 1960

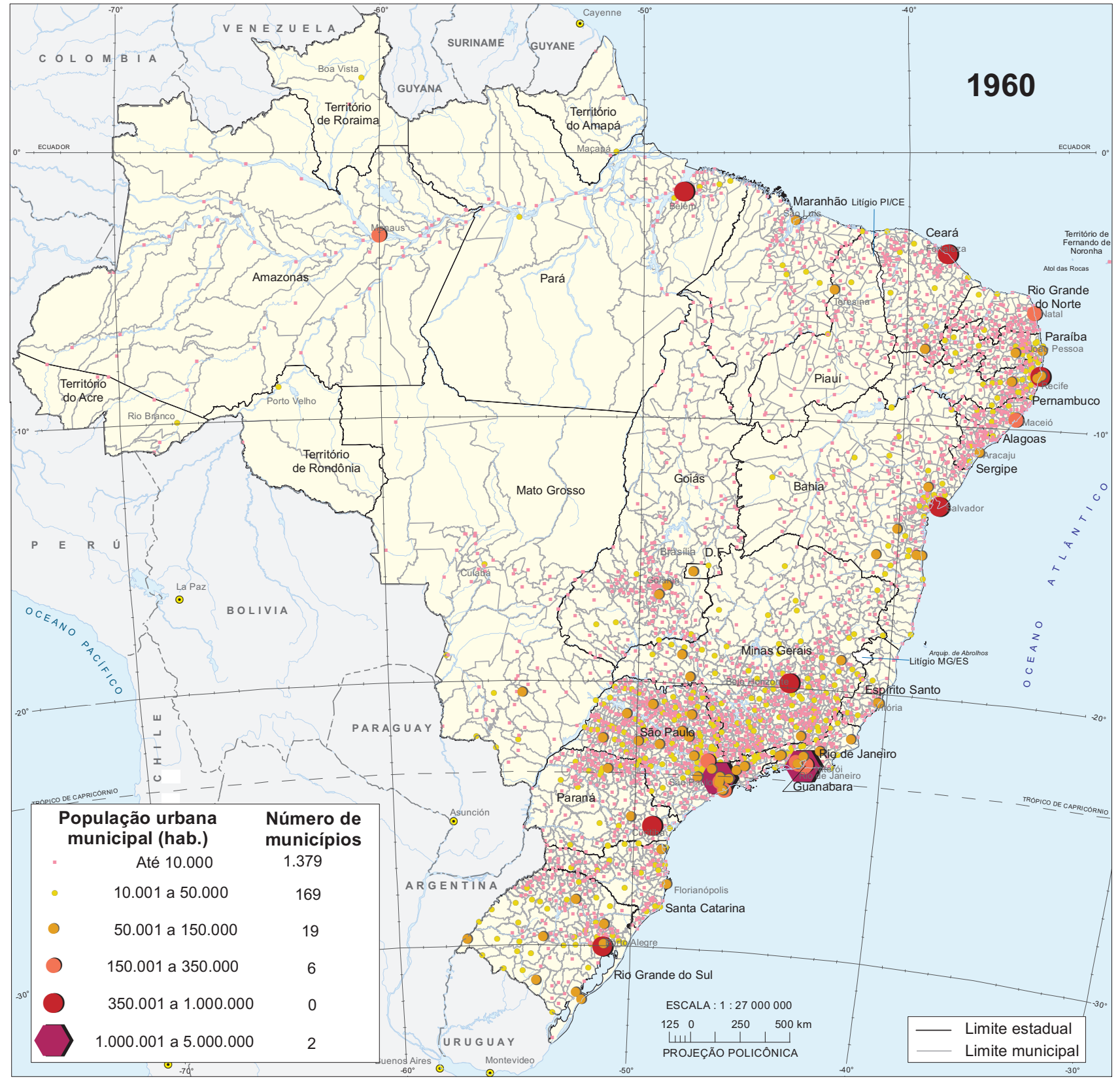

Fonte: IBGE, Censo Demográfico 1960.

Notas: 1. O território federal de Guaporé passou a ser denominado Rondônia e o de Rio Branco passou a Roraima.

2. Outra parte do litígio entre Minas Gerais e Espírito Santo foi solucionada. 


\section{Mapa 3 - Evolução da população urbana - 1991}

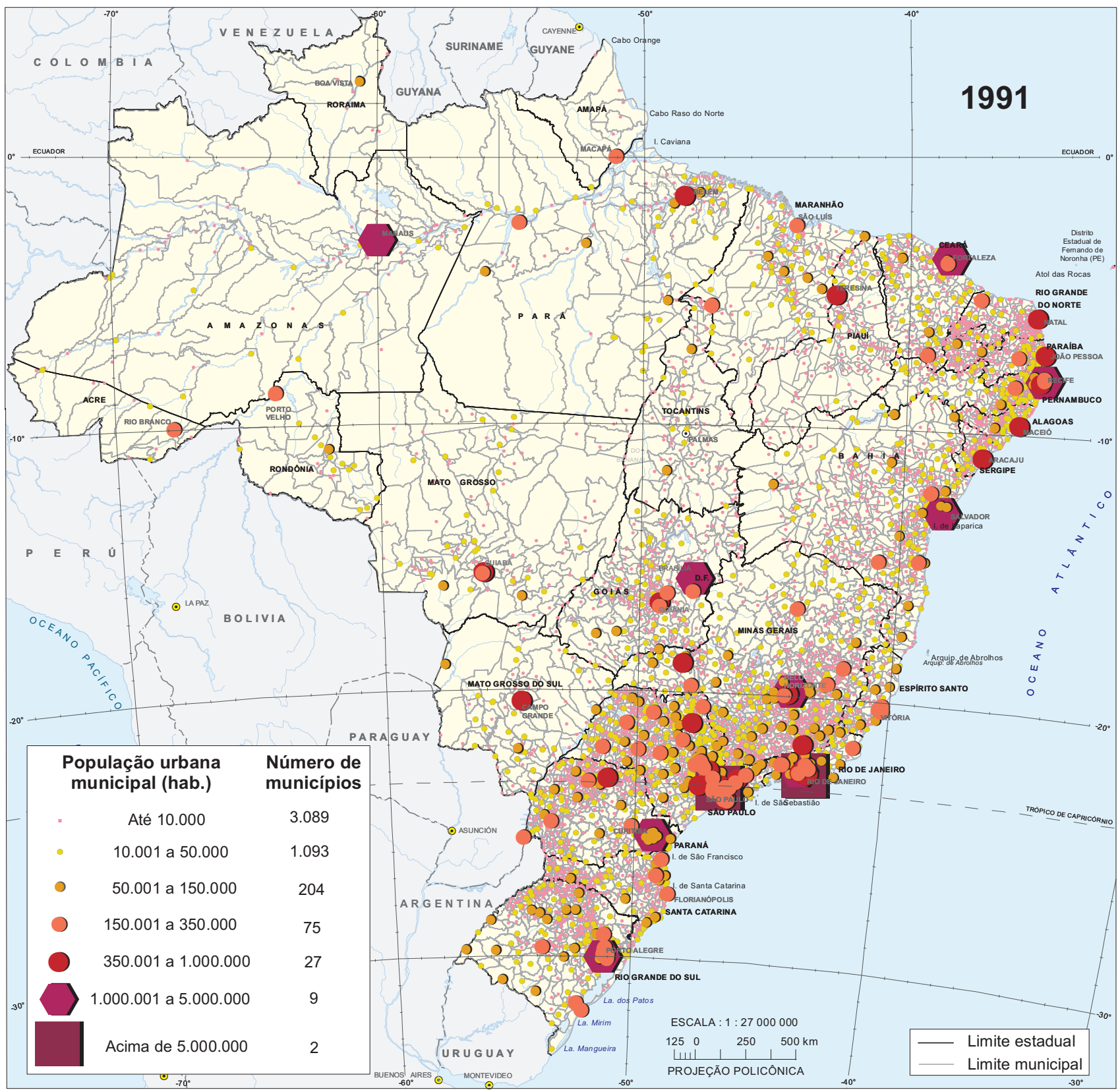

Fonte: IBGE, Censo Demográfico, 1991.

Notas: 1. Rondônia foi elevado à categoria de estado em 1982.

2. Pela Constituição Federal de 1988, o antigo Estado de Goiás foi dividido para formar os estados de Goiás e Tocantins. Os territórios de Roraima e Amapá foram elevados a estado e Fernando de Noronha passou a ser território estadual de Pernambuco. 
Mapa 4 - Evolução da população urbana - 2010

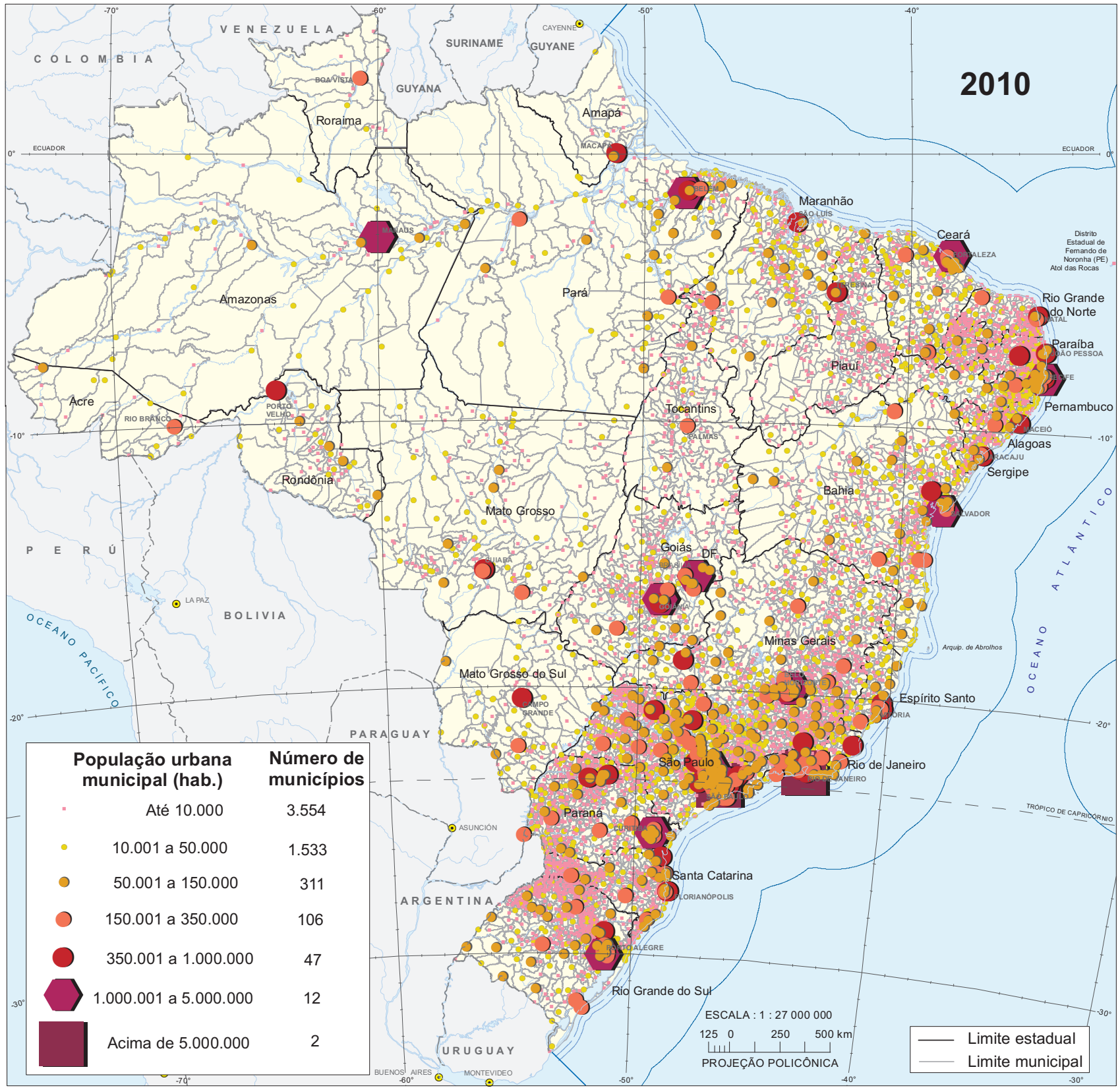

Fonte: IBGE, Censo Demográfico 2010.

Nota: A linha divisória entre os estados do Acre e Amazonas foi alterada. 
O critério brasileiro para estabelecer a situação urbana legal de determinado espaço pode parecer excessivamente político e tecnicamente frágil, posto que se restringe a que a área "seja sede de distrito ou município"; entretanto, como será apresentado, adiante, no tópico $\mathbf{O}$ processo de emancipação de municípios, há uma série de requisitos a cumprir, que envolvem um número expressivo de pessoas, com cargos políticos ou não, para que essa situação seja alcançada.

Conforme mencionado anteriormente, esses critérios vêm recebendo críticas por parte de estudiosos há muitos anos, como será analisado no tópico Críticas ao critério brasileiro de determinação de espaços urbanos.

O conceito de urbano, atrelado que está à sociedade na qual se insere, varia, conforme afirmam autores como Beaujeu-Garnier (1983), Ledrut (1971) e Castells (1983), conforme o país e a sociedade. O Brasil, com sua diversidade inscrita em sua sociedade e em todos os níveis da Federação, é formado por grupos sociais diferentes em muitos aspectos; assim, a atual legislação, ao delegar aos estados e municípios que estabeleçam eles próprios seus espaços urbanos, respeita suas diferenças.

\section{A legislação brasileira e sua origem}

A determinação legal para a diferenciação de espaços urbanos e rurais no Brasil é o Decreto-Lei n. 311, de 02.03.1938. Sua redação foi oriunda do projeto de decreto-lei proposto pela Junta Executiva Central do Conselho Nacional de Estatística, encaminhado por seu presidente José Carlos de Macedo Soares ao Presidente da República Getúlio Vargas, junto a uma exposição de motivos. Nesse último documento, eram solicitadas providências no sentido de reparar "a desordem e a confusão que sempre reinaram no quadro territorial do Brasil" (SOARES, 1939, p. 149).

Os documentos encaminhados à Presidência da República foram elaborados a partir da Convenção Nacional de Estatística de 1936, realizada com membros dos governos federal e estaduais. Um dos objetivos da Convenção era "aprovar as bases da constituição e regulamentação do Conselho Nacional de Estatística e assentar as medidas necessárias à integração do quadro federativo do Instituto Nacional de Estatística", e, ainda, estabelecer "cláusulas de compromisso entre os altos Poderes representados". A cláusula 14ª estabelecia, dentre outras providências atinentes aos estados, a "atribuição da categoria e foros de cidade e vila segundo critérios específicos claramente fixados em lei" (INSTITUTO NACIONAL DE ESTATÍSTICA, 1936, p. 21).

A cláusula 15a enfatizava a necessidade de identificação das populações urbana e rural, observava o respeito às diferenças entre os estados federados e destacava a urgência na delimitação das áreas urbanas e rurais, mantendo a possibilidade de que a sede municipal fosse uma cidade ou uma vila.

Embora não tenha sido expresso, está subentendido que, para essa Convenção, as cidades e vilas, sede de municípios, eram espaços urbanos, sendo os demais rurais. Assim, 
o atendimento a interesses estatísticos e administrativos, ensejava que os estados determinassem, por ato do respectivo governo, os limites dessas cidades e vilas que comporiam o quadro urbano do município.

A importância em estabelecer um ordenamento territorial, no que se referia aos municípios, fez com que o tema voltasse à pauta da Assembleia Geral Ordinária do Conselho Nacional de Estatística, em julho de 1937.

Em dezembro de 1937, o Presidente José Carlos de Macedo Soares, do Instituto Nacional de Estatística, encaminhou ao Presidente da República o documento por meio do qual solicitava que as cláusulas 14a e 15a da Convenção Nacional de Estatística de 1936 fossem transformadas em lei federal, junto a um projeto de decreto-lei. O encaminhamento do pleito a Getúlio Vargas mostra que Macedo Soares duvidava da capacidade de atendimento, no tempo necessário, às cláusulas pactuadas pelos representantes dos governos estaduais presentes à Convenção Nacional de Estatística de 1936, que as tinham assumido como compromisso a ser honrado (CONSELHO NACIONAL DE ESTATÍ́STICA, 1943, p. 166).

O documento enfatizava a necessidade de que fosse implementada rígida racionalidade na delimitação territorial por meio da sistematização e padronização, tanto dos limites jurisdicionais e de suas sedes quanto das denominações e classificações de ambas. Os principais pontos a carecer de solução eram os seguintes: limites municipais inexistentes ou impossíveis de serem seguidos; áreas municipais descontínuas; problemas relativos à toponímia, como repetições, e diversidade entre a jurisdição e sua sede; diferentes malhas para as jurisdições dos distritos administrativos, judiciários e policiais; e,ainda, incoerência quanto aos foros de cidades, vilas, comarcas e termos.

O Conselho defendia que algum montante populacional fosse estabelecido como critério diferenciador entre cidades e vilas que deveriam sediar circunscrições administrativas e judiciárias, com um "espírito de sistema". Para fins estatísticos e administrativos, Macedo Soares defendia também o estabelecimento de critérios que delimitassem e classificassem o espaço em urbano, suburbano e rural.

Também, em dezembro de 1937, foi enviado ao Ministério da Justiça um projeto de decreto-lei sem número, que seguiu anexo à Resolução n. 26, de 15.12.1937, e redigido pela Junta Executiva Central do Conselho Nacional de Estatística, afirmando que, segundo a Constituição em vigor, era da competência da União realizar o recenseamento geral da população e que, para tanto, era preciso "promover a efetiva e racional delimitação das circunscrições administrativas e judiciárias, a identificação das zonas urbanas e rurais e a classificação das localidades segundo categorias padronizadas" (CONSELHO NACIONAL DE ESTATÍ́STICA, 1937, p. 1).

As considerações iniciais do projeto indicavam que o município seria a base da organização administrativa e judiciária, tendo a cidade como sede, e que cada município seria dividido em distritos, cuja sede seria a vila. Estabelecia também um mínimo de duzentas moradias para as sedes dos novos municípios a serem instalados e de trinta para as novas sedes distritais, além da delimitação dos quadros urbano, suburbano e rural mapeados em planta própria (CONSELHO NACIONAL DE ESTATÍSTICA, 1937). 
A criação de distritos deveria ser da competência estadual, apenas seu parcelamento em subdistritos caberia aos governos municipais. Objetivando consolidar as malhas de distritos administrativos e judiciários em uma única, o projeto propunha a manutenção de todos os distritos então existentes, mesmo os que tivessem sido criados por atos dos governos municipais, desde que não houvesse intercessão de suas circunscrições.

O Conselho Nacional de Estatística obteve a confirmação do sucesso de sua empreitada, em 07 de março, quando foi publicado, o Decreto-Lei n. 311, de 1938, dispondo sobre a divisão territorial do País. As considerações iniciais se referem à execução do recenseamento geral da população e às demandas da Convenção Nacional de Estatística e da Assembleia do Conselho Nacional de Estatística, dizendo textualmente:

Considerando que o Art. 15ㅇ da Constituição confere à União a competência de resolver definitivamente sobre os limites do território nacional e fazer o recenseamento geral da população;

$[\ldots]$

Considerando, ainda, os compromissos assumidos nas cláusulas XIV e XV da Convenção Nacional de Estatística, a Resolução n. 59, de 17 de julho de 1937, da Assembléia Geral do Conselho Nacional de Estatística, e, finalmente, o critério por este firmado na Resolução n. 60, de 17 de julho de 1937, da Assembléia Geral, para o cômputo das unidades do quadro territorial da República,

Decreta:

[...]

Art. 3ํㅗ $\mathrm{A}$ sede do município tem a categoria de cidade e lhe dá o nome.

Art. 4ㅇ O distrito se designará pelo nome da respectiva sede, a qual, enquanto não for erigida em cidade, terá a categoria de vila.

Parágrafo único. No mesmo distrito não haverá mais de uma vila.

Art. 5o Um ou mais municípios, constituindo área contínua, formam o termo judiciário, cuja sede será a cidade ou a mais importante das cidades compreendidas no seu território e dará nome à circunscrição.

Art. $6^{-}$

Observado, quanto à sede e à continuidade do território, o disposto no artigo anterior, um ou mais termos formam a comarca.

$[\ldots]$

Art. 11Nenhum novo distrito será instalado sem que previamente se delimitem os quadros urbano e sub-urbano da sede, onde haverá pelo menos trinta moradias.

Art. 12 enhum município se instalará sem que o quadro urbano da sede abranja no mínimo duzentas moradias.

Art. 13ํㅡㄹ Dentro do prazo de um ano, contado da data desta lei, ou da respectiva instalação, se ulterior, os municípios depositarão na Secretaria do Diretório Regional de Geografia, em duas vias autenticadas, o mapa do seu território.

$[\ldots]$

Parágrafo $2^{\circ} \mathrm{O}$ município que não der cumprimento ao disposto neste artigo terá cassada a autonomia e o seu território será anexado a um dos municípios vizinhos, ao qual fica deferido o encargo, aberto novo prazo de um ano, com idêntica sanção (BRASIL, 1938). 
O Decreto-Lei n. 311, de 1938 regulamentou a distinção entre cidade e vila, garantiu que seus nomes fossem os mesmos do município e distrito que sediavam, hierarquizou as divisões territoriais administrativa e judiciária, estabeleceu número mínimo de moradias para novas cidades e vilas e garantiu o mapeamento de todos os municípios.

Poucas foram as determinações dessa legislação que deixaram de viger no País, a saber: embora proibidos, ainda há alguns poucos casos de municípios com áreas descontínuas; o número mínimo de moradias para cidades e vilas foi substituído pelo o de população na Constituição Federal do Brasil de 1967, que atualmente varia conforme a legislação estadual; e os municípios nunca mais foram responsabilizados pelo próprio mapeamento. Embora a extinção de municípios seja ainda prevista em lei, não costuma acontecer, houve casos de municípios extintos no ano de 1964, os quais, segundo Lordello de Mello (1992)' , foram justos em sua maioria.

Esse mesmo Decreto-Lei proporcionou avanços concretos para o conhecimento e a organização padronizada do Território Nacional. Sua implantação conferiu uma base espacial sistematizada, não apenas para apoiar as estatísticas, o que em si já guarda grande importância, mas também para proporcionar maior consistência às informações sobre o ordenamento territorial e sua administração. Pela primeira vez foram mapeados todos os municípios do País, possibilitando a visualização dos seus limites, assim como dos limites entre os espaços urbanos e rurais.

Nenhum outro documento legal, incluindo três Constituições Federais, alterou o estabelecido quanto ao significado de urbano e de rural, conservando-se o entendimento de que todas as cidades e vilas são urbanas, e que o espaço rural é o que lhes é externo (BRASIL, 1986; BRASIL, 2009). Quanto ao número de moradias para novas cidades e vilas, há legislação específica e atualizada nas duas últimas Constituições Federais.

A Constituição Federal de 1967 estabeleceu, da Lei Complementar n. 1, de 09.11.1967, os requisitos para emancipação de novos municípios, o que implicou em determinar o tamanho mínimo para que uma nova cidade fosse criada. Eram exigidos: população superior a 10 mil habitantes na área pretendida para o novo município, sendo $10 \%$ eleitores, cinco milésimos da receita estadual de impostos, e 200 casas na futura cidade.

Esse critério único para todo o Brasil era, antes de tudo, a negação das enormes e conhecidas desigualdades existentes, uma vez que a reunião de 10 mil pessoas encerra realidades totalmente distintas a depender da fração do território em que ocorre. Do mesmo modo, a geração de cinco milésimos da receita estadual oriunda de impostos apresenta distribuição tão ou mais desigual que a referente à população. Entretanto, esta legislação vigorou até o final da década de 1980 quando foi substituída por leis que ainda vigem atualmente.

A Constituição Federal do Brasil de 1988 delegou aos estados o poder de estabelecer os requisitos à emancipação de seus municípios, o que proporcionou diferenças quantitativas e qualitativas entre os estados (BRASIL, 2009). Manteve a competência estadual, que sempre

\footnotetext{
1 O caso mais contundente relatado pelo autor é o de uma sede de município localizada no barco do prefeito, ancorado próximo a Manaus.
} 
houve, de determinar os requisitos e os procedimentos necessários à criação de distritos, atribuição que, em alguns estados, foi delegada aos próprios municípios.

Todos os estados mantiveram o critério de valor mínimo para a população de um novo município; alguns adotaram valores percentuais da população do estado; outros passaram a considerar o valor do município de menor população e a associar o mínimo populacional à distância da sede do município de origem.

Manteve-se, também, como critério, o percentual de eleitores na população. Exige-se, ainda, a geração de renda mínima na área a ser emancipada, geralmente, um percentual sobre o valor da receita tributária ou da oriunda de impostos do estado.

Em praticamente todos os estados, há exigências com relação à futura sede municipal quanto a número mínimo de casas, moradias, ou prédios; construções disponíveis para abrigar a Prefeitura e a Câmara de Vereadores; escolas de primeiro grau; posto de saúde; serviço público de água, dentre muitas outras.

Essa legislação expressa a autonomia estadual para a criação de novos municípios conquistada com a redemocratização política do País na década de 1980. Sua análise não permite associações entre maiores facilidades para emancipar o maior ou menor desenvolvimento econômico do estado. As inúmeras desigualdades, que caracterizam o Brasil, são também identificadas no fracionamento dos territórios estaduais, tanto pelos recortes herdados de períodos passados, quanto pelos desmembramentos que continuam a acontecer de maneira muito diferenciada, sugerindo, mesmo, tratar-se de uma estratégia estadual que transcende seus governos.

Embora expressos de forma clara e inequívoca, nem sempre esses requisitos legais são respeitados pelas próprias Assembleias Legislativas que os estabeleceram. Veiga e outros (2001) apontam alguns exemplos de municípios que, não obstante de emancipação recente, não atendem aos requisitos previstos em lei, contribuindo para a conclusão do autor de que toda a estrutura de determinação de espaços urbanos no País deva ser alterada. Nesse sentido, pode-se afirmar que o maior apreço à legislação vigente seria suficiente para evitar emancipações municipais indevidas e, portanto, passíveis de críticas estruturais.

Conforme visto anteriormente, alguns estados estabelecem critérios para a criação de distritos, outros delegam essa atribuição aos municípios, dado o seu caráter exclusivamente administrativo. Sua sede com categoria de vila é, entretanto, delimitada por perímetro urbano, estabelecido em lei municipal, fazendo com que seu território, economias e população sejam legalmente urbanos.

Os requisitos para a criação de distritos, em termos populacionais, são muito díspares, assim como o número de construções na sede. São muito restritas as exigências que visam ao atendimento básico das necessidades da população, como a oferta de escolas e postos de saúde, por exemplo.

Em 1996, houve a reinterpretação da Emenda Constitucional n. 15, de 12.09.1996, que implementou duas mudanças importantes quanto à emancipação municipal: a primeira trata da lei estadual de criação, que passou a depender de prazo a ser estipulado por lei complementar federal, que nunca foi elaborada, o que, a rigor, passou a impedir qualquer 
emancipação; a segunda alteração foi quanto à realização de plebiscito, requisito básico à criação de um município, que passou a ser realizado também na área remanescente do(s) município(s) de origem (BRASIL, 1996).

O Projeto de Lei do Senado n. 98, de 23.04.2002, transformado no Projeto de Lei Complementar n. 416, de 17.10.2008, estabeleceu critérios gerais para a emancipação de municípios, dentre outras alterações territoriais, a saber: determinou $10 \%$ de eleitores subscrevendo o requerimento inicial; montante mínimo de população variando de 5 mil a 10 mil habitantes, conforme a Grande Região do País; eleitorado igual ou superior a 50\% da população; núcleo urbano constituído, dotado de infraestrutura compatível com a condição de município e com 10\% a mais de imóveis que a média dos municípios do estado; e arrecadação estimada 10\% maior que a média dos municípios do estado. Cumpridas essas exigências, ainda estabeleceu a necessidade de realização de estudos de viabilidade econômico-financeira, político-administrativa, socioambiental e urbana, indicando os órgãos que devem ser consultados. Esse Projeto de Lei Complementar, aprovado no Congresso, foi vetado, em 2013, pelo poder Executivo, com o argumento de que haveria ônus excessivo ao erário (BRASIL, 2008).

Em 2014, novo projeto de lei foi apresentado com critérios semelhantes ainda mais rigorosos. O Projeto de Lei do Senado n. 104 de 26.03.2014 elevou para 20\% o total de eleitores da área a ser emancipada a subscreverem o requerimento inicial; aumentou o montante populacional mínimo em valores regionais, variando de 6 mil a 20 mil habitantes; manteve a exigência quanto ao núcleo urbano consolidado com número de imóveis maior que a média dos menores municípios do estado; e estabeleceu área mínima para o futuro município, segundo a Grande Região a que pertence. E, ainda, conservou a exigência acerca dos estudos de viabilidade econômico-financeira, político-administrativa, socioambiental e urbana com maior detalhamento, determinando que fossem contratados e custeados pelos governos estaduais. Além disso, reiterou que os novos municípios contemplassem todos esses requisitos sem que os municípios de origem deixassem de atendê-los. Apesar de todas essas exigências, esse Projeto de Lei Complementar foi igualmente vetado pelo poder Executivo (BRASIL, 2014).

Desde 1996, quando houve a reinterpretação da Emenda Constitucional n. 15, de 12.09.1996, não deveria ter havido sequer uma emancipação municipal, ficando os projetos estaduais no aguardo da lei federal, mas não foi o que aconteceu. Muitos municípios que de fato existem foram emancipados de forma juridicamente irregular, pois a lei complementar federal que deveria determinar o período para apresentação das leis estaduais nunca foi formalizada, criando uma situação complexa, que está a depender de parecer do Supremo Tribunal Federal.

A emancipação de municípios é uma das formas de incremento dos espaços urbanos; as demais são a criação de um distrito com sua vila, a expansão de uma cidade ou vila por meio da ampliação do perímetro urbano, ou o adensamento populacional de uma cidade ou vila já existente.

Em termos de mudanças na vida cotidiana da população, a primeira forma, isto é, a emancipação de novos municípios é, certamente, a que causa maior impacto no curto prazo. 
Cada novo município significa o surgimento de uma nova cidade, com o aparato institucional correspondente, produzindo efetiva mudança local no ordenamento do território por meio do redirecionamento dos fluxos da população próxima para atendimento às necessidades básicas e de acesso ao Estado.

Cigolini (2009), analisando diversos trabalhos acerca do tema, identificou aqueles que defendem a emancipação municipal, ao contrário dos que não a apoiam. Para os primeiros, a melhora da qualidade de vida local, em razão da implantação de serviços essenciais como agências bancárias, escolas de nível médio, postos de saúde e outros, justifica as despesas com a instalação de uma nova prefeitura e Câmara de Vereadores. Para aqueles que julgam indevidas as emancipações municipais, as despesas financeiras se sobrepõem aos ganhos da população.

\section{O processo de emancipação de municípios}

A emancipação de um município passa pelo cumprimento de uma série de requisitos e exige o envolvimento de um grande número de pessoas e instituições. O processo começa com a formação de uma Comissão de Emancipação composta por pessoas do local que deseja se tornar município. Em alguns estados, esse pleito só pode ser encaminhado se a área pretendente já for um distrito.

Essa Comissão de Emancipação encaminha documento à Assembleia Legislativa do seu estado, com assinatura e, em alguns casos, firma reconhecida de um número legalmente determinado de eleitores residentes na área a ser emancipada. Além da manifestação dos eleitores, há estados em que o pleito depende da assinatura de um ou mais deputados ou do governador.

No documento elaborado pela Comissão de Emancipação e encaminhado à Assembleia Legislativa, são informados os limites ou, pelo menos, as vilas e povoados que formarão o município e também a localidade que abrigará a sede do futuro município. Na Assembleia Legislativa, uma comissão interna, que pode ser a Comissão de Constituição e Justiça ou a Comissão de Revisão Territorial, dependendo do estado, verifica o cumprimento dos primeiros requisitos e acompanha toda a tramitação do processo.

O projeto de criação do município é elaborado, apresentando o limite detalhado por meio de memorial descritivo e de mapa, e encaminhado a alguns órgãos que prestarão informações necessárias ao processo. Ao órgão responsável pela geografia ou cartografia do estado compete a verificação dos limites quanto ao fechamento do polígono, à observação de inexistência de área descontínua no futuro município e nos de origem, e à estabilidade e identificação das linhas e pontos constituintes do limite.

Ao IBGE, na maioria dos casos, é solicitado que informe, com base no Censo Demográfico mais recente, a população residente na área apresentada pelo projeto de criação, assim como o número de casas ou construções no aglomerado indicado para abrigar a sede 
do futuro município. O número de eleitores é solicitado à Justiça Eleitoral, e as informações sobre arrecadação são solicitadas às Secretarias Estaduais de Fazenda.

Cumpridos todos os requisitos pelo pretenso município, sem que os de origem tenham deixado de atender a nenhum deles, a comissão responsável, na Assembleia Legislativa, solicita ao Tribunal Regional Eleitoral a realização de plebiscito, consultando tanto a população da área do futuro município quanto da área remanescente dos municípios de origem, conforme determina a Emenda Constitucional n. 15, de 12.09.1996.

Após a aprovação pelas populações envolvidas, o projeto de criação é votado em plenário da Assembleia Legislativa, e, se aprovado, a lei de criação é publicada, no Diário Oficial do Estado, com os limites do município, o nome e a indicação da sede. Essa publicação, entretanto, não consagra ao município o direito de existência para quaisquer fins, apenas a sua instalação, que se dará com a posse do prefeito, é que determina o nascimento real de uma nova unidade político-administrativa. Nas eleições seguintes, independentemente de a quais cargos se destinem, o Tribunal Regional Eleitoral inclui a votação, no novo município, que escolherá também seu primeiro prefeito, vice-prefeito e vereadores. Em primeiro de janeiro do ano consecutivo, ocorrem a posse dos eleitos e a assinatura da Ata de Instalação do Município, dando início à sua efetiva existência.

Todo o processo de emancipação de um município é, portanto, determinado por legislações estadual e federal e conta, necessariamente, com a aprovação dos deputados estaduais e das populações envolvidas, tanto daquela que reside na área a ser emancipada, quanto a da área remanescente dos municípios de origem. A importância dessa explanação é mostrar que esse processo envolve muitas pessoas, apresenta regras claras e legalmente estabelecidas, e que, se por vezes essas não são cumpridas, a deficiência não está no processo, mas na falta do correto cumprimento às leis.

Enquanto a legislação federal e/ou estadual tem estabelecido os critérios quanto ao tamanho das novas cidades e vilas desde 1938, a legislação municipal tem sido a responsável pela determinação de seus limites. Cabe à Prefeitura e à Câmara de Vereadores estabelecer o perímetro urbano da cidade e das vilas em lei municipal, que pode não ser específica para esse fim. A área contida pelo perímetro urbano é legalmente urbana, assim como tudo o que dela constar. Por exclusão, as áreas não urbanas são legalmente rurais, conservando-se, portanto, o preceito estabelecido pelo Decreto-Lei n. 311, de 02.03.1938.

O estabelecimento do limite da cidade concretamente identificado no terreno é bem mais simples no discurso do que na prática. Todas as proposições teóricas acerca do urbano e da cidade mostram que, desde que as muralhas em torno da cidade deixaram de existir, nem sempre é fácil identificar, no terreno, uma linha que identifique o início das manifestações da vida urbana ou da cidade. Frequentemente, a transição entre a cidade e o campo ocorre em uma zona de transição, uma franja rural-urbana que já foi qualificada de suburbana, termo que com o tempo adquiriu outro significado. Entretanto, a lei estabelece que a divisa seja feita em linha e não em área. 
Mas como conciliar a linha exigida pela lei com a área na qual mais frequentemente ocorre a transição? Ambas precisam ser respeitadas, uma por ser legalmente determinada, e a outra por ser a expressão da organização daquela sociedade. Essa conciliação é especialmente importante nos momentos em que é necessário classificar cada fração do espaço, cada casa, cada pessoa.

Visando contornar esse problema, o IBGE, que é um órgão usuário desse recorte espacial, construiu uma classificação que, sendo mais complexa que a legal, possibilita o respeito e a preservação mais acurada das características de vida das populações residentes nessas zonas de transição. Essa classificação, proposta por Fredrich, Brito e Rocha (1983), foi adotada a partir do Censo Demográfico 1991 e, além de incluir os setores, que são as unidades espaciais de coleta, nas situações urbana ou rural, estabelece oito tipos que distinguem as áreas urbanizadas das não urbanizadas, assim como diferenciam os aglomerados rurais (X RECENSEAMENTO..., 2005).

Como visto anteriormente, os critérios de determinação do caráter urbano a certas áreas do território brasileiro têm recebido críticas contundentes por parte de profissionais que se dedicam quer a estudos da organização espacial, como os geógrafos, quer a informações oriundas de levantamentos baseados nesses recortes espaciais. As críticas identificadas por este trabalho foram oferecidas principalmente por geógrafos e se dirigem aos fundamentos da opção brasileira de basear, na estrutura político-administrativa, a identificação de espaços urbanos.

\section{Críticas ao critério brasileiro de determinação de espaços urbanos}

A crítica mais antiga foi divulgada já na publicação dos resultados do Recenseamento Geral do Brasil de 1940. Nas páginas introdutórias, onde são apresentadas as definições dos termos empregados no levantamento, criticava-se a inclusão de aglomerados muito pequenos na categoria de cidades, em decorrência de serem sedes municipais, conforme estabelecido pelo Decreto-Lei n. 311, de 02.03.1938 (RECENSEAMENTO..., 1950-1952).

A decisão governamental de que todas as sedes municipais passassem a ser cidades foi considerada inadequada por parte do corpo técnico da Instituição, mesmo considerando que o referido Decreto-Lei tenha sido elaborado a partir de documentos do Conselho Nacional de Estatística.

Alguns anos mais tarde, em 1956, Aroldo de Azevedo, em seu clássico estudo "Vilas e cidades do Brasil colonial", apresentou também sua crítica ao estabelecido pelo Decreto-Lei n. 311, de 1938. Nas palavras do autor:

Evidentemente, seria um erro afirmar que esses 1.890 centros urbanos devem ser considerados verdadeiras cidades, de acordo com o conceito geográfico desta palavra, pois a grande maioria não apresenta as características culturais e sociais, a estrutura, as características demográficas e as funções geralmente apontadas pelos geógrafos para que possam ser como tais classificados. 
Acreditamos estar mais próximos da realidade se tomarmos como limite mínimo para a conceituação das cidades (na falta de outro critério) a população urbana de 10.000 hab. Nesta hipótese, existiriam, em 1950, apenas 204 aglomerados urbanos que mereceriam aquela designação, no ponto de vista da Geografia (AZEVEDO, 1956, p. 5-6, grifo do autor).

Em 1963, Pedro Geiger publicou sua discordância quanto à legislação brasileira que, para o autor, considerava as cidades aglomerados que não se caracterizavam como tal. Geiger (1963, p. 8) questionava que se atribuísse categoria de cidade às sedes de municípios com "menos de 1000 habitantes, casario tosco, baixo e disperso".

O limite inferior de 1 mil habitantes para as cidades sugerido por Geiger se coaduna com o Decreto-Lei n. 311, de 1938, que estabeleceu 200 moradias para as novas sedes municipais. O problema grave era quanto às sedes já existentes e com valores de população e/ ou de construções muito aquém do legal e do conceitualmente razoável.

Do mesmo modo, o "casario tosco e baixo" devia ser corriqueiro nas pequenas cidades, com casas feitas de pau-a-pique e recobertas com folhagem da vegetação local, condizentes com as precárias condições econômicas da maioria da população brasileira. $\mathrm{O}$ problema da dispersão, destacado por Geiger (1963), possivelmente o de maior relevância na determinação de uma cidade, não foi enfrentado sequer pela legislação de 1967, ao não incluir nenhuma exigência quanto à densidade.

Em 1983, a Fundação Carlos Chagas Filho de Amparo à Pesquisa do Estado do Rio de Janeiro - FAPERJ publicou um trabalho, coordenado por Lysia Maria Cavalcanti Bernardes (1983), sobre aglomerados fluminenses de pequeno porte, assim considerados as "cidades (até 30000 habitantes), vilas e outros aglomerados populacionais", em cuja primeira página criticava o critério político-administrativo de classificar como urbanas todas as sedes municipais e distritais.

Dentre as cidades e vilas do interior do Estado do Rio de Janeiro, 89\% possuíam, segundo o Censo Demográfico 1980, menos de 30 mil habitantes, e muitas, menos de 10 mil habitantes. Segundo esse levantamento, "tais localidades, oficialmente reconhecidas como urbanas, correspondem, via de regra, a pequenos embriões urbanos ou simples povoados rurais, na maioria das vezes dotados de funções e equipamentos urbanos mínimos" (BERNARDES, 1983, p. 13).

A crítica dirigia-se, portanto, às mínimas dimensões, assim como às parcas funcionalidades oferecidas pelas localidades, que, muitas vezes, sequer constituíam aglomerados visivelmente percebidos. A interpretação da palavra urbano nesse trabalho da FAPERJ parece guardar o conceito ligado à reunião de pessoas, casas e funções, não ao de dinamismo e modernidade que já se construía no período.

Naquele ano de 1983, a legislação em vigor para a emancipação de novos municípios era a Lei Complementar n. 1, de 9 de novembro de 1967, da Presidência da República, que determinava a todas as áreas que almejassem se tornar municípios, que possuíssem ao menos 10 mil habitantes em seu território, incluindo as populações urbanas da cidade e das vilas e a população rural. 
Fany Davidovich e Olga Fredrich (1988), analisando a urbanização brasileira na década de 1980, mostraram as altas taxas de crescimento da população urbana, chamaram a atenção para a estratégia de ocupação urbana de áreas de fronteira e perceberam tendências de homogeneização do comportamento social segundo o modo de vida urbano. Discordaram, assim como os autores anteriormente apresentados, do critério administrativo para o estabelecimento de espaços urbanos no Brasil.

As autoras apresentaram exemplos tanto de cidades que pela pequena população não deveriam dispor da condição de espaço urbano, quanto da situação oposta exemplificada pela cidade de São Luís, no Estado do Maranhão, em que a ocupação com características urbanas expandia-se para muito além dos limites legais da cidade. Embora o referido trabalho tivesse como objetivo "analisar as características da urbanização no Brasil", com destaque para "o decênio 1970-1980" (DAVIDOVICH; FREDRICH, 1988, p. 15), não houve, por parte das autoras, a intenção de apresentar sugestões para o aperfeiçoamento da definição utilizada e por elas reconhecida como inadequada.

Outras críticas foram identificadas avançando para além das anteriormente apresentadas, no sentido de contribuírem com propostas concretas para solucionar, ou ao menos minimizar, as reconhecidas dificuldades quanto ao estabelecimento de critérios objetivos para a determinação de espaços urbanos no Brasil. A primeira, também na década de 1980, foi formulada por Lysia Bernardes, Sergio Lordello dos Santos e Fernando Nalcacer e publicada à época pelo Instituto Paranaense de Desenvolvimento Econômico e Social - IPARDES - Fundação Édison Vieira. (BERNARDES; SANTOS; NALCACER, 1983); a segunda, apresentada, no ano 2000, por Ricardo Abramovay (2000), em publicação do Instituto de Pesquisa Econômica Aplicada - IPEA; e a terceira, divulgada, nos anos 2001 e 2002, por José Eli da Veiga (2002a), em artigos no jornal O Estado de São Paulo, alguns dos quais foram posteriormente reunidos em livro.

No ano de 1983, o trabalho do então Instituto Paranaense de Desenvolvimento Econômico e Social - IPARDES - Fundação Édison Vieira em associação com Ministério do Interior, coordenado por Lysia Bernardes (BERNARDES; SANTOS; NALCACER, 1983), discutiu o conceito de determinação de espaços urbanos no Brasil, analisado sob os aspectos tributário e urbanístico, comparou-o aos de outros países e elaborou propostas concretas e politicamente factíveis para o aperfeiçoamento da legislação brasileira.

Os autores começavam o texto mostrando que a inadequação da definição de urbano era reconhecida por todos. Destacavam também a dificuldade de adequação que teria qualquer critério que viesse a ser adotado no Brasil em face de enormes diferenças entre a maioria das cidades e as grandes metrópoles.

A simetria atribuída aos municípios, embora fosse considerada indevida pelos autores, era percebida como parte integrante da história municipal brasileira, tendo sido mantida tanto por todas as Constituições Federais, quanto pelas legislações estaduais, que poderiam, conservando a igualdade no que se refere à autonomia municipal, ter estabelecido algumas diferenças, por exemplo, quanto a procedimentos de administração financeira.

Admitiam a existência de municípios que era contestada quer por terem sido indevidamente criados sob a inobservância da legislação, quer por terem deixado de atender 
a essa última, em face de reduções populacionais ou de perdas de agentes econômicos. A resolução desse problema possuía duas alternativas:

A primeira solução, aparentemente mais simples, mas reconhecidamente inviável, seria a extinção daqueles municípios de extensão territorial pequena e de recursos escassos, que tem como sede núcleos de dimensão populacional também pequena, que melhor se enquadrariam como vilas. A fusão de pequenos municípios desse tipo [...] poderia resultar em melhor racionalização na utilização dos recursos disponíveis, sem dúvida, mas não encontraria qualquer apoio político pois implicaria, para a população local, em perda de sua autonomia (BERNARDES; SANTOS; NALCACER, 1983, p. 38)

Considerando impossível a implementação da extinção de municípios, os autores indicavam, como segunda proposta de solução, estudos do Instituto Brasileiro de Administração Municipal - IBAM; do IBGE; e do Conselho Nacional de Desenvolvimento Urbano - CNDU. Nesses estudos, haviam sido apresentadas propostas de "criação de categorias diferentes de municípios" sem, entretanto, alterar suas autonomias, mas considerando principalmente as diferenças na complexidade de suas sedes. O estudo do IBAM se detivera na maior ou menor concentração urbana; o do IBGE, por meio de técnicas estatísticas, classificara os municípios em rural, rural/urbano, urbano/rural e urbano; e o do CNDU distribuíra-os entre as categorias rural, de capital, de interesse de segurança nacional e geral ou padrão. Dentre os problemas que a implementação de sistemas como esses acarretaria, os autores destacavam sua aceitação em termos políticos. Apontavam para o perigo do autoritarismo, memória viva na época da elaboração do estudo, e da transitoriedade da classificação, indicando exemplos de municípios que, em poucos anos, tinham deixado de ter economias eminentemente agrícolas passando a industriais, ou que se transformaram em centros turísticos, o que requereria periódica revisão da classificação. Ainda no sentido de apontar dificuldades, lembravam que um número expressivo de cidades de grande porte tinha suas economias voltadas principalmente para a agropecuária e questionavam se, ainda assim, seriam classificados como urbanas.

Concluíam que a única alternativa para diminuir os efeitos negativos da "uniformização do critério administrativo" seria o estabelecimento, por parte dos estados, de alguma classificação de cidades, não de municípios, de modo a, garantindo a autonomia destes, diferenciá-las em termos de "atuação e exigências", proporcionando "maior racionalidade no tratamento do urbano" (BERNARDES; SANTOS; NALCACER, 1983, p. 44).

Mesmo reconhecendo que os critérios referentes ao montante populacional e à densidade eram os mais utilizados como indicadores de áreas urbanas, julgavam que os ligados à funcionalidade seriam mais adequados, não apenas em termos conceituais, mas principalmente para a aplicação em países como o Brasil, que apresenta enormes desigualdades regionais.

Para os autores, o que propiciava o caráter urbano a um aglomerado era a implantação de infraestrutura mínima que garantisse a permanência e o bem-estar das famílias. Reconheciam a dificuldade de estabelecer esse limite, mas identificavam que o montante de 1 mil habitantes ou 200 moradias seria suficiente para assegurá-la. Avaliavam que um aglomerado dessas dimensões seria capaz de gerar demandas por infraestrutura, comércio e serviços em volume suficiente para ser considerado urbano. A consecução desses investimentos dependeria de um certo aparato administrativo, proporcionado pelo governo municipal, 
e de receitas próprias que tivessem sido geradas no município ou para ele transferidas por outro ente federativo.

Lembravam que a desigualdade da distribuição espacial da população no Brasil exigiria que à União coubesse apenas fornecer as linhas gerais de caracterização dos espaços urbanos, enquanto aos estados deveria competir a fixação dos critérios objetivos estabelecendo limites mínimos na determinação de suas cidades e vilas.

Admitiam a existência de áreas urbanas externas às cidades e vilas, assim como vilas sem o caráter urbano. Não incluíam as cidades, por menos populosas que fossem, nessa categoria não urbana, por avaliar que a presença do aparato político-administrativo era capaz, por si só, de propiciar a complexidade necessária e suficiente à inclusão da cidade no conjunto dos aglomerados urbanos.

Alguns anos depois, embora a referida "inadequação da definição de urbano" ainda permanecesse, ao menos parte das recomendações desse trabalho do IPARDES - Fundação Édison Vieira foi atendida pela Constituição Federal do Brasil de 1988, com a delegação aos estados do estabelecimento de requisitos mínimos para que novos municípios fossem emancipados.

Em todos os estados, são exigidos o valor mínimo de população para o futuro município, assim como os elementos de infraestrutura para a futura sede. O aspecto referente à densidade foi o único, dentre os sugeridos pelos autores, a ser enunciado pela lei de poucos estados, embora seja frequente a referência à ocorrência de "unidade do território" para a criação de cidades.

Ricardo Abramovay (2000) apresentou suas críticas ao método brasileiro de estabelecimento de espaços rurais. Julgava inadequados tanto o critério administrativo de identificação de espaços urbanos, quanto a determinação de espaços rurais feita por exclusão. Propunha que o País fosse dividido em regiões urbanas e regiões rurais, foco principal do seu trabalho, que incluiriam campos e cidades. As regiões rurais não seriam estabelecidas a partir da predominância da ocupação da mão de obra em atividades agropecuárias, as quais, no entender do autor, não representam as áreas rurais, dado o estabelecimento cada vez mais frequente de outras atividades. Discorda também da utilização de critério calcado no estabelecimento de patamar mínimo de população das localidades, embora o considere o menos inadequado.

Para o autor, há três características indicadas para determinar as áreas que devam ser consideradas rurais: 1 ) as fortes relações com a natureza em termos éticos, afetivos e como fonte de rendimento; 2 ) a baixa densidade demográfica no campo aberto e nas pequenas cidades, nos quais são maiores as probabilidades de se desenvolverem relações de vizinhança que nas grandes cidades; e 3) a dependência ao sistema urbano, mostrando que as áreas rurais mais prósperas são as que possuem maior interação com os grandes centros urbanos (ABRAMOVAY, 2000).

Nos anos 2001 e 2002, José Eli da Veiga manteve uma coluna no jornal O Estado de São Paulo, na qual publicou diversos artigos, posteriormente reunidos em livro (VEIGA, 2002a), criticando os resultados do Censo Demográfico 2000 que, mesmo preliminares, apontavam para o aumento, em termos absolutos e relativos, da população urbana brasileira.

O autor apresentava duas discordâncias acerca do critério brasileiro para a determinação dos espaços urbanos: a primeira, e mais fundamental, era a de que, na mesma linha de Abramovay (2000), os municípios não deveriam possuir parte urbana e parte rural, mas, 
sim, serem classificados por inteiro em municípios urbanos ou municípios rurais; e a segunda crítica, decorrente da primeira, referia-se ao limite mínimo de população e densidade que deveriam ter os municípios a serem classificados como urbanos (VEIGA, 2002a). Ele distinguia, de início, os municípios brasileiros sobre os quais não havia dúvida quanto ao caráter urbano:

Não há habitantes mais urbanos do que os residentes nas 12 aglomerações metropolitanas, nas 37 demais aglomerações e nos outros 77 centros urbanos identificados pela pesquisa que juntou excelentes equipes do IBGE - Instituto Brasileiro de Geografia e Estatística, do Ipea - Instituto de Pesquisas Econômicas Aplicadas, e da Unicamp - Universidade de Campinas: Caracterização e Tendências da Rede Urbana do Brasil (1999). Nessa teia urbana, formada pelos 455 municípios dos três tipos de concentração, estavam 57\% da população em 2000. Esse é o Brasil inequivocamente urbano (VEIGA, 2002a, p. 32, grifos do autor).

Para classificar todos os demais municípios, apontava como o ideal um "índice de pressão antrópica", que ainda estava por ser construído, e que determinaria, como mais rurais, os municípios de território mais intocado, enquanto, no extremo oposto, estariam os municípios mais urbanos que seriam, portanto, os mais artificializados. Em não havendo tal índice, utilizava informações de montante populacional e densidade demográfica para considerar

de pequeno porte os municípios que têm simultaneamente menos de 50 mil habitantes e menos de 80 hab/km2 e de médio porte os que têm população no intervalo de 50 a 100 mil habitantes, ou cuja densidade supere os 80 hab/ $\mathrm{km}^{2}$, mesmo que tenham menos de 50 mil habitantes (VEIGA, 2002a, p. 34).

Dessa classificação resultava, segundo o autor, que cerca de $80 \%$ dos municípios brasileiros, nos quais residiam aproximadamente $30 \%$ da população, seriam percebidos como "essencialmente rurais", e 10\% dos municípios que abrigavam cerca de $13 \%$ da população estariam em posição intermediária entre os essencialmente urbanos e os essencialmente rurais, os quais seriam denominados "intermédios" (VEIGA, 2002a, p. 34).

Em artigo posterior à publicação do livro, o autor afirma que deveriam ser consideradas urbanas apenas as aglomerações que dispusessem de livraria, funcionalidade que, no seu entender, garantiria a existência de outras que propiciariam ao aglomerado o verdadeiro caráter urbano. Nas palavras do autor, "povoações que não chegam a ter livraria também não costumam cumprir as funções exigidas para que uma aglomeração seja cidade" (VEIGA, 2002b, p. 1).

O trabalho de Veiga (2002a), embora trate enfaticamente das questões relativas à divisão e classificação do território, tem por objetivo principal defender o desenvolvimento das regiões por ele identificadas como rurais por meio da diversificação das atividades. Como afirmado em várias passagens, a população dessas regiões há muito já não tem seu trabalho restrito à agricultura, pecuária e pesca; ao contrário, dedica-se cada vez mais à prestação de serviços que, em geral, propicia melhor remuneração. 


\section{Considerações finais}

As críticas aos critérios brasileiros de determinação de espaços urbanos fixam-se, como foi visto, no limite inferior do conjunto das cidades e vilas. Não há argumentação contrária ao fato de que os grandes aglomerados sejam cidades e urbanos; a discussão centra-se nas pequenas cidades. A principal questão é a identificação mais precisa das categorias de cidade e de espaço urbano.

As críticas propostas em Recenseamento geral do Brasil 1940 (1950); Azevedo (1956); Geiger (1963); Bernardes (1983); Santos e Nalcacer (1983); Davidovich e Fredrich (1988); Bernardes e Abramovay (2000); e Veiga (2002a; 2002b) apontam para a inadequação de que seja atribuído a pequenas cidades tal título, assim como que lhes seja imputado caráter urbano. Estariam esses autores, a partir de suas criticas, sugerindo o fim da diferenciação entre os pequenos aglomerados, sendo ou não legalmente cidades, e o campo? Abramovay (2000) e Veiga (2002a) afirmam que sim, ao propor a divisão do Território Nacional em áreas urbanas e rurais, homogeneizando-as em grandes conjuntos.

As demais críticas, entretanto, apontam para a deficiência no limite mínimo do que se deva considerar cidade, aspecto que, quanto a novas cidades, provavelmente seria resolvido com o simples respeito à legislação vigente. A proposta de Bernardes, Santos e Nalcacer (1983), embora mantenha a atual estrutura básica, contempla ajustes referentes à retirada de vilas, cuja pequena complexidade socioeconômica não justifique sua permanência entre os espaços urbanos, e, pela via oposta, a inclusão nesses espaços de povoados, que, portanto, sequer são sedes de distritos, avaliados como suficientemente complexos. Apenas esses autores se debruçaram sobre a complexa situação que é criada diante da redução de montante populacional e de atividade econômica ocorrida em municípios já consolidados, que deixam, assim, de atender aos requisitos mínimos aceitos para se manterem como tal.

O estabelecimento de espaços urbanos no Brasil segue, há muitos anos, regras legalmente estabelecidas; respeita, desde o final da década de 1980, as diferenciações estaduais; e envolve grande número de agentes locais, de instâncias políticas estaduais e de instituições públicas das esferas federal e estaduais. Se, ainda assim, são verificadas emancipações indevidas, a falha não está no sistema, mas sim nas inadequações inseridas em seu cumprimento por aqueles a quem cabe fiscalizar sua implementação.

Os projetos de legislação recentemente propostos pelo Senado e vetados pelo poder Executivo contemplavam, além de exigências já previstas em legislações anteriores como as relativas ao montante mínimo de população, construções, rendimento e infraestrutura, estudos prévios de viabilidade econômico-financeira, político-administrativa, socioambiental e urbana.

Finalmente, o argumento divulgado pelo Executivo para o veto destaca a persistência da centralidade das questões financeiras nas decisões políticas em torno desse tema ao apontar apenas para o aumento de despesas, deixando em aberto, para a análise geopolítica, o impacto da criação de município sobre as condições objetivas de vida dos pequenos aglomerados populacionais do País. 
Com efeito, a transformação de uma vila em cidade pode representar tanto a universalização do acesso a uma agência bancária, a uma escola de nível médio e/ou aos recursos para transporte de pacientes em consultas, exames e internações, como, em termos institucionais, o ethos urbano, mesmo da pequena cidade, pode representar para a organização da vida socioeconômica do interior. Isso não é pouco, e a pesquisa geográfica tem muito a contribuir e avançar nesse debate.

\section{Referências}

X RECENSEAMENTO geral do Brasil: GR-7.01: manual de delimitação dos setores e das zonas de trabalho de 1990. Rio de Janeiro: IBGE, Diretoria de Geociências, 1990. 78 p. Disponível em: <http://biblioteca.ibge.gov.br/visualizacao/instrumentos_de_coleta/ doc0207.pdf>. Acesso em: mar. 2016.

ABRAMOVAY, R. Funções e medidas da ruralidade no desenvolvimento contemporâneo. Brasília, DF: Instituto de Pesquisa Econômica Aplicada - IPEA, 2000. 28 p. (Texto para discussão, n. 702). Disponível em: <http://www.ipea.gov.br/agencia/images/stories/PDFs/ TDs/td_0702.pdf>. Acesso em: mar. 2016.

ABREU, M. de A. Geografia histórica do Rio de Janeiro (1502-1700). Rio de Janeiro: A. Jakobson Estúdio: Rio Prefeitura, 2010. 2 v.

AZEVEDO, A. de. Vilas e cidades do Brasil colonial: ensaio de geografia urbana retrospectiva. Boletim da Faculdade de Filosofia, Letras e Ciências Humanas da Universidade de São Paulo, São Paulo, 1956.

BEAUJEU-GARNIER, J. Geografia urbana. Lisboa: Fundação Calouste Gulbenkian, 1983. $525 \mathrm{p}$.

BERNARDES, L. M. C. (Coord.). Urbanização do interior fluminense: análise dos aglomerados de pequeno porte. Rio de Janeiro: Fundação de Amparo à Pesquisa do Estado do Rio de Janeiro - FAPERJ, Coordenadoria de Geografia e Estatística, 1983. 204 p.

BERNARDES, L. M. C.; SANTOS, S. R. L. dos; NALCACER, F. C. (Org.). Redefinição do conceito de urbano e rural. Curitiba: Ipardes-Fundação Édison Vieira; Ministério do Interior, Conselho de Desenvolvimento Urbano, 1983. 84 p. Disponível em: <http://www.ipardes. gov.br/biblioteca/docs/redefinicao_urbano_rural_12_83.pdf>. Acesso em: mar. 2016.

BRASIL. Congresso. Câmara dos Deputados. Projeto de Lei Complementar n. 416, de 16 de outubro de 2008. Dispõe sobre o procedimento para a criação, a incorporação, a fusão e o desmembramento de Municípios, para regulamentar o parágrafo 4o do Art. 18, da Constituição Federal; tendo pareceres: da Comissão de Desenvolvimento Urbano e Interior, pela aprovação dos Projetos de Lei Complementar ns 130/96, 138/96 e 151/97, apensados, com substitutivo... Disponível em: <http://www.camara.gov.br/proposicoesWeb/prop_most rarintegra; jsessionid=821AAB046C7E5E8E44208C0EBF9969E3. node2 codteor $=1022562 \&$ filename=Avulso+-PLP+416/2008>. Acesso em: mar. 2016. 
. Projeto de Lei Complementar n. 416-A, de 4 de junho de 2013. Dispõe sobre o procedimento para a criação, a incorporação, a fusão e o desmembramento de municípios, nos termos do parágrafo 4o do artigo 18 da Constituição Federal. Disponível em: <http://www.camara.gov.br/proposicoesWeb/prop_mostrarintegra?codteor=1096917\&f ilename $=$ Tramitacao-RDF+1+\%3D\%3E+PLP+416/2008>. Acesso em: mar. 2016.

Senado Federal. Projeto de Lei n. 104, de 31 de março de 2014. Dispõe sobre o procedimento para a criação, a incorporação, a fusão e o desmembramento de municípios, nos termos do parágrafo 4ํㅜ do artigo 18 da Constituição Federal e dá outras providências. Disponível em: <http://www.senado.leg.br/atividade/materia/getPDF.asp?t=147713\&tp=1>. Acesso em: mar. 2016.

Constituição (1988). Constituição da República Federativa do Brasil. Brasília, DF, [2009]. Disponível em: <http://www.presidencia.gov.br/legislacao> Acesso em: mar. 2016.

[Constituição]. Constituições do Brasil: (de 1824, 1891, 1934, 1937, 1946, 1967 e suas alterações). Brasília, DF: Senado Federal, 1986. 2 v.

. Emenda Constitucional n. 15, de 12 de setembro de 1996. Dá nova redação ao parágrafo $4^{\circ}$ do Art. 18 da Constituição Federal. Diário Oficial [da União], Brasília, DF, n. 179, 13 set. 1996. Seção 1, p. 18110-18111. Disponível em: <http://www.presidencia.gov. br/legislacao>. Acesso em: mar. 2016.

Decreto-Lei n. 311, de 2 de março de 1938. Dispõe sobre a divisão territorial do país e dá outras providências. Coleção de leis da República Federativa do Brasil de 1938, Rio de Janeiro: Imprensa Nacional, v. 1, p. 438-440, 1938. Disponível em: <http:// www2.camara.leg.br/legin/fed/declei/1930-1939/decreto-lei-311-2-marco-1938-351501publicacaooriginal-1-pe.html>. Acesso em: mar. 2016.

Lei Complementar n. 1, de 9 de novembro de 1967. Estabelece os requisitos mínimos de população e renda pública e a forma de consulta prévia às populações locais para a criação de novos municípios, e dá outras providências. Diário Oficial da União, Brasília, DF, 10 nov. 1967. Seção 1, p. 11391. Disponível em: <http://www4.planalto.gov. br/legislacao/legislacao-1/leis-complementares-1/leis-complementares-1/1967 \#content>. Acesso em: mar. 2016.

. Lei n. 10.257, de 10 de julho de 2001. Regulamenta ao arts. 182 e 183 da Constituição Federal, estabelece diretrizes gerais da política urbana e dá outras providências. Diário Oficial [da] República Federativa do Brasil, Brasília, DF, ano 138, n. 133, 11 jul. 2001. Seção 1, p. 1. Disponível em: <http://www.presidencia.gov.br/legislacao>. Acesso em: mar. 2016.

CASTELLS, M. A questão urbana. 3. reimpr. São Paulo: Paz e Terra, 1983. 590 p. (Pensamento crítico, v. 48).

CIGOLINI, A. A. Território e criação de municípios no Brasil: uma abordagem históricogeográfica sobre a compartimentação do espaço. 2009. 210 f. Tese (Doutorado)-Programa de Pós-Graduação em Geografia, Universidade Federal de Santa Catarina - UFSC, Florianópolis, 2009. Disponível em:<https://repositorio.ufsc.br/bitstream/handle/123456789/92531/268885. pdf? sequence=1>. Acesso em: jun. 2015. 
CONSELHO NACIONAL DE ESTATíSTICA (Brasil). Junta Executiva Central. Resolução n. 26, de 15 de dezembro de 1937. Sugere ao Governo Federal a decretação de disposições orgânicas relativas à divisão administrativa e judiciária do território nacional. Diário Oficial [dos] Estados Unidos do Brasil, [Rio de Janeiro], ano 76, n. 296, 28 dez. 1937. Seção 1, p. 25656.

DAVIDOVICH, F. R.; FREDRICH, O. M. B. de L. Urbanização no Brasil. In: SILVA, S. T. (Coord.). Brasil: uma visão geográfica nos anos 80. Rio de Janeiro: IBGE, Departamento de Geografia, 1988. p. 13-85. Disponível em: <http://biblioteca.ibge.gov.br/visualizacao/ livros/liv80970.pdf>. Acesso em: mar. 2016.

EVOLUÇÃO da divisão territorial do Brasil: 1872-2010. Rio de Janeiro: IBGE, Diretoria de Geociências, 2011. 261 p. (Documentos para disseminação. Memória institucional, 17). Disponível em: <http://biblioteca.ibge.gov.br/visualizacao/livros/liv55077.pdf>. Acesso em: mar. 2016.

FREDRICH, O. M. B. L.; BRITO, S. R. de; ROCHA, S. Conceituação e operacionalização da categoria de aglomerados rurais como situação de domicílio para fins censitários. Revista Brasileira de Estatística, Rio de Janeiro: IBGE, v. 44, n. 173-174, p. 199-225, jan./jun. 1983. Disponível em: <http://biblioteca.ibge.gov.br/visualizacao/periodicos/111/rbe_1983_v44_ n173_n174.pdf>. Acesso em: mar. 2016.

GEIGER, P. P. Evolução da rede urbana brasileira. Rio de Janeiro: Centro Brasileiro de Pesquisas Educacionais - CBPE, 1963. 462 p. (Sociedade e educação).

INSTITUTO NACIONAL DE ESTATÍSTICA (Brasil). Convenção Nacional de Estatística. Rio de Janeiro: Ministério do Trabalho, Indústria e Commercio, Departamento de Estatística e Publicidade, 1936. 32 p. Disponível em: <http://biblioteca.ibge.gov.br/visualizacao/livros/ liv14968.pdf>. Acesso em: mar. 2016.

LEDRUT, R. Sociologia urbana. Rio de Janeiro: Forense, 1971. 208 p.

MELLO, D. de L. A multiplicação de municípios no Brasil. Revista de Administração Municipal, Rio de Janeiro: Instituto Brasileiro de Administração Municipal - IBAM, v. 39, n. 203, p. 23-38, abr. 1992.

RECENSEAMENTO geral do Brasil: 1ำ de setembro de 1940. Rio de Janeiro: Serviço Gráfico do Instituto Brasileiro de Geografia e Estatística, 1950-1952. 3 v.; 22 partes. (Série Nacional). Disponível em: <http://biblioteca.ibge.gov.br/pt/bibliotecacatalogo?view=detalhes\&id=765>. Acesso em: mar. 2016.

ROSA, L. R.; FERREIRA, D. A. de O. As categorias rural, urbano, campo, cidade: a perspectiva de um continuum. In: SPÓSITO, M. B. E.; WHITAKER, A. M. (Org.). Cidade e campo: relações e contradições entre urbano e rural. São Paulo: Outras Expressões, 2006. 409 p.

SOARES, J. C. de M. Exposição dirigida ao senhor presidente da republica [sic] pelo presidente do Instituto Brasileiro de Geografia e Estatistica [sic]. Revista Brasileira de Geografia, Rio de Janeiro: IBGE, ano 1, n. 2, p. 148-154, abr. 1939. Disponível em: <http://biblioteca.ibge. gov.br/visualizacao/periodicos/115/rbg_1939_v1_n2.pdf>. Acesso em: mar. 2016. 
VEIGA, J. E. Cidades imaginárias: o Brasil é menos urbano do que se calcula. Campinas: Autores Associados, 2002a. 304 p.

VEIGA, J. E. Dos povoados, aldeias, vilas, cidades e municípios. O Estado de São Paulo, São Paulo, 20 maio 2002b. Economia, p. 17.

VEIGA, J. E. et al. O Brasil rural precisa de uma estratégia de desenvolvimento. 2. Reimpr. Brasília, DF: Ministério do Desenvolvimento Agrário, Conselho Nacional de Desenvolvimento Rural Sustentável - CNDRS, Núcleo de Estudos Agrários e Desenvolvimento Rural - NEAD, 2001. 108 p. (Textos para discussão, n. 1). Texto provisório para discussão. Disponível em: $<$ http://www.mda.gov.br/sitemda/pagina/nead-textos-para-discuss\%C3\%A3o $>$. Acesso em: mar. 2016. 